\title{
Individual differences in insomnia
}

Citation for published version (APA):

van de Laar, M. (2017). Individual differences in insomnia: implications of psychological factors for diagnosis and treatment. [Doctoral Thesis, Maastricht University]. Maastricht University. https://doi.org/10.26481/dis.20170503mvdl

Document status and date:

Published: 03/05/2017

DOI:

10.26481/dis.20170503mvdl

Document Version:

Publisher's PDF, also known as Version of record

\section{Please check the document version of this publication:}

- A submitted manuscript is the version of the article upon submission and before peer-review. There can be important differences between the submitted version and the official published version of record.

People interested in the research are advised to contact the author for the final version of the publication, or visit the DOI to the publisher's website.

- The final author version and the galley proof are versions of the publication after peer review.

- The final published version features the final layout of the paper including the volume, issue and page numbers.

Link to publication

\footnotetext{
General rights rights.

- You may freely distribute the URL identifying the publication in the public portal. please follow below link for the End User Agreement:

www.umlib.nl/taverne-license

Take down policy

If you believe that this document breaches copyright please contact us at:

repository@maastrichtuniversity.nl

providing details and we will investigate your claim.
}

Copyright and moral rights for the publications made accessible in the public portal are retained by the authors and/or other copyright owners and it is a condition of accessing publications that users recognise and abide by the legal requirements associated with these

- Users may download and print one copy of any publication from the public portal for the purpose of private study or research.

- You may not further distribute the material or use it for any profit-making activity or commercial gain

If the publication is distributed under the terms of Article $25 \mathrm{fa}$ of the Dutch Copyright Act, indicated by the "Taverne" license above, 
Summary 


\section{Summary}

The present thesis describes the complex relationship between insomnia, psychiatric comorbidity and other psychosocial factors. It highlights the importance of psychodiagnostics in the evaluation of chronic insomnia. Furthermore, it describes how personality and coping research might attribute to an understanding of different phenotypes of insomnia as well as support the enhancement of quality of life in patients with insomnia and might guide the prediction of treatment results.

Chapter 1 is the general introduction of this thesis and describes the background of our study and research questions. The pathophysiology, nosological classification and treatment of insomnia and the relationship with personality traits and psychiatric disorders are discussed.

In chapter 2 "The role of personality traits in insomnia" we reviewed studies on insomnia and personality and concluded that neuroticism, internalization and anxious personality traits characterize insomniacs in general. However, due to a lack of longitudinal data and other methodological issues, such as small sample sizes and lack of psychodiagnostics it was difficult to conclude whether these personality traits are predisposing for insomnia. Specific differences in personality traits might just as well be a consequence of insomnia. In addition, certain personality traits may be related to the response to (cognitive) behavioral treatment. We also stressed that personality should not be viewed as a single predisposing factor, but should be assessed as a part of a larger group of interacting psychological and physiological factors involved in the predisposition to and perpetuation of chronic insomnia. For future research we recommended longitudinal studies including different psychosocial variables and clear psychodiagnostic assessment of the research population.

In chapter 3 "Subjective sleep characteristics in insomnia with and without psychiatric comorbidity" we discussed differences between subjective sleep diary variables between three groups. We found that patients with psychiatric comorbidity do not necessarily show more severe subjective complaints. Patients with comorbid anxiety disorders showed a sleep efficiency that was significantly higher than patients with primary insomnia. Also they showed a sleep efficiency-score that was more than $20 \%$ higher than patients with comorbid mood disorders. While subjective total bedtimes were comparable, the total sleep time was on average 2 hours longer in patients with comorbid anxiety disorders than in patients with comorbid mood disorders. We also found evidence that the main problem in patients with comorbid anxiety disorders involves sleep fragmentation. These results show that tailored CBT-I treatment may vary according to the presence and type of psychiatric comorbidity. Patients with comorbid anxiety disorders might benefit more from sleep restriction while patients 
with primary insomnia and comorbid depressive disorders might show better results through stimulus control procedures.

In chapter 4 "General quality of life in insomnia with and without psychiatric comorbidity" we examined psychosocial factors and sleep variables and their possible contribution to a higher quality of life in insomniacs. We found that the association of these variables with general quality of life (QOL) varies according to the presence of psychiatric comorbidity. Remarkably, the ISI-score was not associated with QOL in primary insomniacs. On the other hand, fatigue was negatively associated with QOL and seems to be more important for general well-being than subjective sleep diary measures such as sleep efficiency or total sleep time in both groups. High discrepancies in social support and low Extraversion are associated with lower QOL in primary insomniacs. Including an assessment of these factors during intake procedures might guide more tailored treatments in which (social) activation might enhance QOL in these patients. In patients with comorbid insomnia, insomnia severity (ISI-score) was negatively associated with QOL as well as the anxiety and depressive symptoms (HADSscore). This stresses the importance of adding CBT-I elements in the treatment of psychiatric disorders in patients who also suffer from insomnia.

Chapter 5 "Psychiatric comorbidity and coping predict cognitive behavioral treatment effect" focused on the prediction of CBT-I treatment effect by examining personality traits, coping and social support. We found that the presence of a comorbid psychiatric disorder predicts worse treatment results. In our results we found a trend that patients who are following current treatment for their comorbid psychiatric disorder might benefit more from CBT-I than patients who are not engaging in current psychological treatment for the comorbid psychiatric disorder. Also, we found that high refocus on planning independently predicts worse CBT-I treatment results. If a comorbid psychiatric disorder is present, we suggest that it is better to integrate cognitive behavioral treatment for insomnia with psychological treatment for the comorbid psychiatric disorder and not exclusively treat the insomnia problem. Adding specific treatment strategies focusing on the decrease of controlling behavior and thoughts around sleep en promoting acceptance of the sleep problem might gain better treatment results in patients with high refocus on planning.

In chapter 6 "Phenotypes of sleeplessness: stressing the need for psychodiagnostics in the assessment of insomnia" we used cluster analysis to distinguish different phenotypes in patients with insomnia. Our findings stress the need for psychodiagnostic procedures next to a sleep-related diagnostic approach, especially in younger insomnia patients. We identified three clusters. The "moderate insomnia with low psychopathology"-cluster was characterized by relatively normal personality traits, as well as normal levels of anxiety and depressive symptoms in the presence of moderate insomnia severity. The "severe insomnia with moderate psychopathology"- 
cluster showed relatively high scores on the Insomnia Severity Index and scores on the sleep log that were indicative for severe insomnia. Anxiety and depressive symptoms were slightly above the cut-off and they were characterized by below average selfsufficiency and less goal-directed behavior. The "early onset insomnia with high psychopathology"-cluster showed a much younger age and earlier insomnia onset than the other two groups. Anxiety and depressive symptoms were well above the cut-off score and the group consisted of a higher percentage of subjects with comorbid psychiatric disorders. This cluster showed a "typical psychiatric" personality profile. Specific treatment suggestions are given based on the three phenotypes.

In Chapter 7 we discussed the implications of our findings for clinical practice. We concluded that there are strong personality and subjective sleep differences in patients with and without psychiatric comorbidity. Also, there are other factors correlated with general quality of life depending on the presence of psychiatric comorbidity. Therefore, the term insomnia disorder is much too broad and we suggested the introduction of the term comorbid insomnia. Especially in younger patients with insomnia, psychodiagnostics are very important. These patients often show more comorbid psychiatric disorders. Patients with comorbid psychiatric disorders show less positive treatment results after $\mathrm{CBT}-\mathrm{I}$ and we recommend a parallel treatment of the psychiatric disorder when starting with CBT-I. Based on our results we conclude that patients with anxiety disorders might benefit more from sleep restriction and that extra attention should be given towards stimulus control in patients with insomnia and comorbid mood disorders. Adding new promising techniques such as acceptance commitment therapy (ACT) and mindfulness-based treatment might enhance treatment effect in specific groups of patients who respond less well to CBT-I. Future research should focus on the benefits of implementing tailored interventions based on type of psychiatric comorbidity and cognitive coping style. 
Samenvatting 


\section{Samenvatting}

In dit proefschrift wordt de complexe relatie tussen insomnie, psychiatrische comorbiditeit en andere psychosociale factoren beschreven. Het belang van psychodiagnostiek in de evaluatie van chronische insomnie wordt benadrukt. Verder wordt in dit proefschrift beschreven hoe onderzoek naar persoonlijkheid en coping kan bijdragen aan het begrip van verschillende fenotypes van insomnie, hoe het de kwaliteit van leven kan vergroten in insomniepatiënten en hoe het kan helpen bij het voorspellen van behandelresultaten.

Hoofdstuk 1 is de algemene introductie van dit proefschrift en beschriff de achtergrond van onze studie en de onderzoeksvragen. De pathofysiologie, nosologische classificatie en behandeling van insomnie en de relatie met persoonlijkheidstrekken en psychiatrische stoornissen worden besproken.

In hoofdstuk 2 "The role of personality traits in insomnia" hebben we onderzoeken ten aanzien van insomnie en persoonlijkheid gereviewd en concludeerden we dat neuroticisme, internalisatie en angstige persoonlijkheidstrekken kenmerkend zijn voor insomniepatiënten in het algemeen. Echter, door een gebrek aan longitudinale data en andere methodologische problemen, zoals kleine groepsgroottes en gebrek aan psychodiagnostiek, was het lastig om te concluderen of deze persoonlijkheidstrekken predisponerend zijn voor insomnie. Het is even waarschijnlijk dat specifieke verschillen in persoonlijkheidstrekken een consequentie zijn van de insomnie. Bepaalde persoonlijkheidstrekken zijn verder mogelijk gerelateerd aan (cognitief) gedragstherapeutisch behandeleffect. We benadrukten ook dat persoonlijkheid niet als enkelvoudig predisponerende factor gezien zou moeten worden, maar als een onderdeel van een grotere groep interacterende psychologische en fysiologische factoren die betrokken zijn in de predispositie en het onderhouden van chronische insomnie. Ten aanzien van toekomstig onderzoek adviseerden we onderzoeken uit te voeren met een longitudinale opzet waarbij aandacht is voor verschillende psychosociale variabelen en duidelijke psychodiagnostiek binnen de onderzoeksgroep.

In hoofdstuk 3 "Subjective sleep characteristics in insomnia with and without psychiatric comorbidity" beschreven we verschillen in subjectieve slaapdagboekvariabelen tussen drie groepen. We vonden dat patiënten met psychiatrische comorbiditeit niet per definitie ernstigere subjectieve klachten laten zien. Patiënten met comorbide angststoornissen hadden een significant hogere slaapefficiëntie dan patiënten met primaire insomnie. Ook hadden zij een slaapefficiëntiescore die meer dan $20 \%$ hoger was dan bij patiënten met comorbide stemmingsstoornissen. Terwijl subjectieve bedtijden vergelijkbaar waren, was de totale slaaptijd 2 uur langer bij patiënten met comorbide angststoornissen in vergelijking met patiënten met comorbide stemmingsstoornissen. Een van de resultaten was ook dat het grootste 
probleem bij patiënten met comorbide angststoornissen te maken heeft met slaapfragmentatie. Deze gegevens laten zien dat CGT-I behandeling kan variëren afhankelijk van de aanwezigheid van psychiatrische comorbiditeit en het type bijkomende psychiatrische stoornis. Patiënten met bijkomende angststoornissen zouden meer baat kunnen hebben bij slaaprestrictie, terwijl patiënten met primaire insomnie en comorbide stemmingsstoornissen betere resultaten zouden kunnen behalen door middel van stimuluscontrole procedures.

In hoofdstuk 4 "General quality of life in insomnia with and without psychiatric comorbidity" onderzochten we psychosociale factoren en slaapvariabelen en hun mogelijke bijdrage aan een hogere kwaliteit van leven bij insomniepatiënten. We vonden dat het verband tussen deze variabelen en de algemene kwaliteit van leven varieerde, afhankelijk van de aanwezigheid van psychiatrische comorbiditeit. Opmerkelijk was dat de ISI-score niet samenhing met QOL in primaire insomniepatiënten. Er was een negatief verband aanwezig tussen vermoeidheid en QOL en vermoeidheid lijkt een belangrijkere factor te zijn voor algemeen welbevinden dan subjectieve slaapdagboekvariabelen zoals slaapefficiëntie en totale slaaptijd. Dit geldt voor beide groepen. Hoge discrepanties in sociale steun en lage extraversie hangen samen met een lagere kwaliteit van leven in primaire insomniepatiënten. Het toevoegen van een onderzoek naar deze factoren tijdens de intake kan bijdragen aan meer op maat gemaakte behandelingen waarbij (sociale) activatie de kwaliteit van leven kan vergroten bij deze patiënten. Bij patiënten met comorbide insomnie was de ernst van de insomnie (ISI-score) negatief geassocieerd met kwaliteit van leven en ditzelfde gold voor de angst- en stemmingsklachten (HADS-score). Dit benadrukt het belang van het toevoegen van CGT-I elementen aan de behandeling van patiënten met psychiatrische stoornissen die ook last hebben van insomnie.

In Hoofdstuk 5 "Psychiatric comorbidity and coping predict cognitive behavioral treatment effect" werd de focus gelegd op voorspellers van CGT-I behandeleffect door onderzoek naar persoonlijkheidstrekken, coping en sociale steun. We vonden dat de aanwezigheid van een comorbide psychiatrische stoornis voorspellend was voor slechtere behandelresultaten. We vonden een trend dat patiënten die gelijktijdig een behandeling kregen voor hun comorbide psychiatrische stoornis meer positief effect zouden kunnen hebben van de CGT-I dan patiënten die deze psychologische behandeling niet kregen. Eén van onze resultaten was verder dat een hogere focus op planning voorspellend was voor slechtere CGT-I behandelresultaten. Als er een bijkomende psychiatrische stoornis aanwezig is adviseren we integratie van CGT-I in een behandeling van deze psychiatrische stoornis in plaats van het alleen behandelen van de insomnie. Het toevoegen van specifieke behandelstrategieën die gericht zijn op het verminderen van controlerend gedrag en gedachten rondom slaap en die de acceptatie van het slaapprobleem bevorderen kunnen voor betere behandelresultaten zorgen bij patiënten die snel geneigd zijn zich te richten op planning. 
In hoofdstuk 6 "Phenotypes of sleeplessness: stressing the need for psychodiagnostics in the assessment of insomnia" gebruikten we een clusteranalyse om verschillende fenotypes van insomnie te kunnen onderscheiden. Onze bevindingen benadrukken het belang van psychodiagnostiek naast een slaapgerelateerde aanpak, vooral bij jongere insomniepatiënten. We identificeerden drie clusters. Het "matige insomnie met lage psychopathologie"-cluster kenmerkte zich door relatief normale persoonlijkheidstrekken en een normaal niveau van angst- en stemmingsklachten in aanwezigheid van matig ernstige insomnieklachten. Het "ernstige insomnie met matige psychopathologie"-cluster liet relatief gezien hoge scores zien op de ISI en slaapdagboekvariabelen die indicatief waren voor ernstige insomnie. Angst- en stemmingsklachten bevonden zich qua ernst net boven de drempelwaarde en dit cluster kenmerkte zich door beneden gemiddelde zelfredzaamheid en minder doelgericht gedrag. Het "vroeg begin van de insomnie met hoge psychopathologie"-cluster had een veel lagere leeftijd en hierbij begon de insomnie eerder dan bij de andere twee groepen. Angst- en stemmingsklachten scoorden sterk boven de drempelwaarde en de groep bestond uit een hoger percentage patiënten met comorbide psychiatrische stoornissen. Dit cluster had een persoonlijkheidsprofiel wat typisch is voor patiënten met psychiatrische stoornissen. Op basis van deze drie clusters worden er specifieke aanbevelingen voor de behandeling gegeven.

In hoofdstuk 7 bespraken we de implicaties van onze bevindingen voor de klinische praktijk. We concludeerden dat er sterke persoonlijkheids- en subjectieve slaapverschillen bestaan tussen patiënten met en zonder psychiatrische comorbiditeit. Ook zijn er verschillende factoren die samenhangen met kwaliteit van leven afhankelijk van de aanwezigheid van psychiatrische comorbiditeit. Daarom is de term "insomniestoornis" te breed en stellen we voor om de term "comorbide insomnie" te gebruiken. Vooral bij jongere insomniepatiënten is psychodiagnostiek erg belangrijk. Deze patiënten hebben vaker comorbide psychiatrische stoornissen. Patiënten met bijkomende psychiatrische stoornissen hebben minder positieve behandelresultaten na CGT-I en we adviseren parallelle behandeling van de psychiatrische problematiek bij het starten van de CGT-I. Aan de hand van onze resultaten concluderen we dat patiënten met bijkomende angststoornissen mogelijk meer baat hebben bij slaaprestrictie en dat er bij patiënten met primaire insomnie en bijkomende stemmingsstoornissen extra aandacht zou moeten worden gegeven aan stimulus controle. Het toevoegen van nieuwe, veelbelovende technieken zoals acceptance commitment therapy (ACT) en mindfulness therapie zou het behandeleffect kunnen vergroten bij specifieke patiëntgroepen die minder goed op CGT-I reageren. Toekomstig onderzoek zou zich kunnen richten op de voordelen van het implementeren van op maat gemaakte behandelingen aan de hand van het type psychiatrische comorbiditeit en cognitieve copingstijl. 